\title{
Noncarious cervical lesions in occlusion service patients: occlusal aspects and risk factors
}

\author{
Lesões cervicais não cariosas em pacientes de serviços de oclusão: aspectos oclusais e fatores de risco
}

Viviane Maria Gonçalves de FIGUEIREDO'

Rosenês Lima dos SANTOS'

André Ulisses Dantas BATISTA'

\section{ABSTRACT}

\section{Objective}

To evaluate the occlusal aspects of patients with and without noncarious cervical injury and identify its risk factors.

\section{Method}

Through a cross-sectional study, 88 patients of both sexes between 18 and 71 years old were evaluated, in Occlusion services in the cities of João Pessoa and Campina Grande. Clinical assessments were performed by a single calibrated examiner to check the occlusal aspects of patients with and without injuries, through descriptive and non-parametric analysis with 5\% significance level and 95\% of confidence interval.

\section{Results}

Parafunctional habits were identified at a frequency of $92.0 \%$ of the patients. Unilateral chewing was not associated with the presence of lesions. The side disocclusion by the canine was prevalent in the whole sample. Occlusal interference in maximal intercuspal position and in nonworking side were presented as risk factors for the higher number of lesions and their development. Wear facets were common in the premolar groups and the maxillary arch in patients with lesions.

\section{Conclusion}

Occlusal factors pose risks for the development and greater number of noncarious cervical lesions.

Indexing terms: Dental occlusion. Functional laterality. Tooth Wear.

\section{RESUMO}

\section{Objetivo}

Observar os aspectos oclusais de pacientes com e sem lesão cervical não cariosa e identificar os fatores de risco das mesmas.

\section{Método}

Através de um estudo transversal foram avaliados 88 pacientes, de ambos os sexos, entre 18 e 71 anos, nos Serviços de Oclusão das cidades de João Pessoa e Campina Grande. Realizaram-se avaliações clínicas, por um único examinador calibrado, para verificar os aspectos oclusais dos pacientes com e sem lesões. Através de análises descritivas e não paramétricas com 5\% de nível significância e $95 \%$ de intervalo de confiança.

\section{Resultados}

Os hábitos parafuncionais foram identificados em uma frequência de $92,0 \%$ dos pacientes. A mastigação unilateral não apresentou associação com a presença das lesões. A desoclusão lateral pelo canino foi prevalente em toda amostra. Interferências oclusais em máxima intercuspidação habitual e lado de não trabalho apresentaram-se como fatores de risco para o maior número de lesões e o desenvolvimento das mesmas. Facetas de desgaste foram frequentes no grupo de pré-molares e no arco superior em pacientes com lesões.

\section{Conclusão}

Fatores oclusais representam risco para o desenvolvimento e maior número de lesões cervicais não cariosas.

Termos de indexação: Oclusão dentária. Lateralidade funcional. Desgaste dos dentes.

\footnotetext{
${ }^{1}$ Universidade Federal da Paraíba, Faculdade de Odontologia. Cidade Universitária, 58051-900, João Pessoa, PB, Brasil. Correspondência para / Correspondence to: VMG FIGUEIREDO.E-mail: <vivi_mfigueiredo@yahoo.com.br>.
} 


\section{INTRODUCTION}

Noncarious Cervical Lesions (NCLs) are defined by the dental tissue loss in the cervical region: of teeth, without the evidence of dental caries origin ${ }^{1-4}$. These injuries are usually found and increasingly common practice in dental clinic. Their etiology and classification are challenging, though ${ }^{4}$. The action of abrasive, erosive and occlusal mechanisms may contribute to the lesion formation, making it of a multifactor source ${ }^{1,4-6}$.

The increased consumption of fruit, sports drinks and oral hygiene habits suggest that these lesions are due to erosion and abrasive habits ${ }^{6-7}$. Patient of occlusion services do not present health habits associated with the presence of lesions, and only the frequency of soft drink consumption was associated with $\mathrm{NCLs}^{8}$.

The occlusal stress from non-axial force (lateral or oblique) on the dental element, can generate microfractures of enamel and dentin in the cervical region ${ }^{1}$. The occlusion as an etiologic factor of NCLs was presented in 1984 by the Tooth Bending Theory, which states that occlusal interferences cause the breakdown of enamel and dentin in the cervical region, resulting in the lesion formation ${ }^{9}$.

The occlusal loading and NCLs has been a subject of extensive research through studies in silico ${ }^{10-12,}$ which demonstrate high cervical stress in non-axial loading conditions on the dental element. However, it is necessary to clinically observe the behavior of these occlusal interferences and check for a possible correlation of these lesions with the occlusal factor.

Based on the above, this study aimed to observe the occlusal aspects of patients with and without noncarious cervical injury and identify its risk factors.

The hypothesis to be tested is that there is an association between occlusal factors and the presence of noncarious cervical lesions

\section{METHODS}

This research is characterized by a cross-sectional and prospective study, that is, the data obtained in this study were generated at the time it was developed. The survey was conducted with patients of the Occlusion services in the cities João Pessoa and Campina Grande. Patients of these services were the study population. A convenience sample of 88 patients was used, based on a previous study in the same services ${ }^{8}$.
Patients of these services, based on a previous study $^{8}$ were in average 31.47 years old, ranging between 18-71 years old; $63.36 \%$ being female and $36.64 \%$ male; in whom $65.90 \%$ of the lesions were present, and in $34.10 \%$ they were absent, with an average of 5.28 injured teeth per patient.

The study included patients with at least 20 functional teeth), who were willing to participate. We excluded patients with periodontal disease, orthodontic, endodontic and occlusal treatment, pregnant women and patients with severe bruxism and mouth opening limitation.

The study was approved by the local ethics committee - University Hospital Lauro Wanderley- HULW CAAE 0399.0.126.000-10. For the implementation of clinical examination was used a calibrated examiner of the study previously conducted in this population ${ }^{8}$.

Data collection was performed by a clinical examination and specific form where variables were raised about occlusal aspects of patients with and without cervical injury.

\section{Variables}

Unilateral chewing: the patient was questioned whether this type of chewing occurred.

Parafunctional habits: the patients were asked about the presence of habits such as, teeth clenching and grinding, nail biting, lips biting, cheeks sucking, tongue sucking, biting objects resting your chin on your hand.

Lateral disocclusion: the lateral disocclusion to the left and right side was classified through the clinical examination into canine guidance (there is contact only of the upper and lower canines), Group function (premolars and upper and lower molars contact) and group partial function (there is contact only at the canine and upper and lower premolar) ${ }^{13}$.

Anterior guidance: it was classified through the clinical examination in anterior guidance (contact only between the anterior teeth), posterior guidance (contact only between the posterior teeth) and combined guidance (contact between the anterior and posterior teeth simultaneously) ${ }^{14}$.

Contact interference in maximal intercuspal position and no nonworking side: the presence of these interferences through clinical examination was observed with the aid of a double-sided articulating film (Accum-film II, Parkell-Farmingdale, USA) together with the miller clamp ${ }^{15}$. 
Wear facets: were analyzed the plaster models of superior and inferior teeth of each patient. The impression was carried out in stock trays with Condensation Silicone

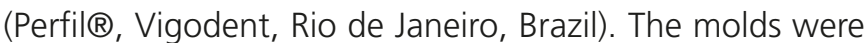
poured with type IV plaster (Durone, Dentsply Industria e Comercio Ltda., Rio de Janeiro, Brazil) with the aid of a plaster vibrator. Once the plaster models were obtained, the occlusal anatomy of the dental elements were analyzed with the aid of a magnifying glass with $4 x$ magnifying power (Bio-Art, São Carlos, Brazil). In order to make easier the viewing of the wear facets, they were marked on the impressions with a graphite pencil with $0.5 \mathrm{~mm}$ diâmetro ${ }^{15}$.

It was used a scale present in the literature ${ }^{16}$ to classify the facets, establishing a degree from 0 to 3 . The grade 0 with no wear, grade 1 minimum wear on the tips of the cusps and occlusal surfaces, grade 2 flattening of
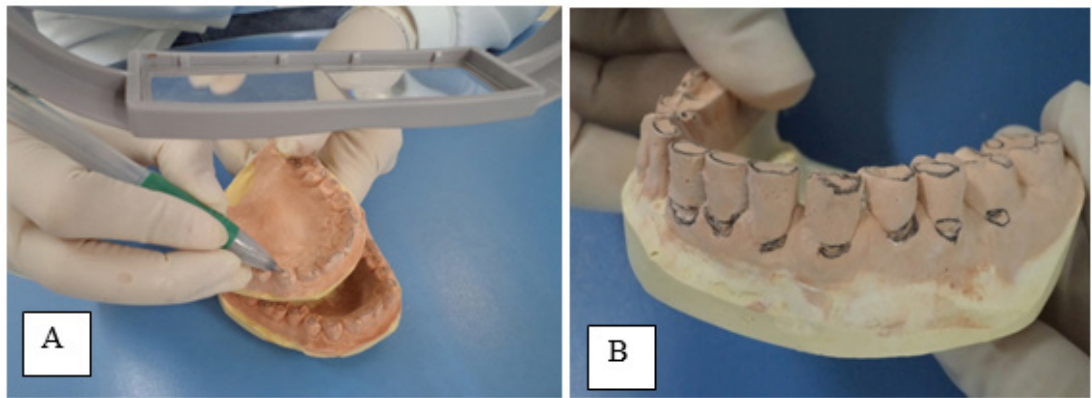

Figure 1. A) Analysis of plaster models with magnifying glass and graphite to mark the wear facets; B) lower model in plaster with wear facets delineated, as well as the noncarious cervical lesions.

the cusps or incisal surfaces and degree 3 total loss of contour and dentin exposure when identifiable (Figure 1).

Data were recorded in a computer program database SPSS (Statistical Package for Social Sciences) for Windows, version 15.0, and analyzed using descriptive and inferential statistics. The Chi-square test estimated the association among variables. The $C$ ramer $V$ coefficient identified the strength of the associations and the relative risk (odds ratio) to identify the risk factor. Guided by the compliance of the distribution of data, corroborated by Komogorov-Smirnov normallity test, which showed a normal divergent distribution of ( $p>0.05)$. Adopted a $95 \%$ confidence interval and a significance level of $5 \%$ ( $p$ $<0.05)$.

\section{RESULTS}

The parafunctions were identified in a prevalence of $92.0 \%$ of the patients. It was found a positive association

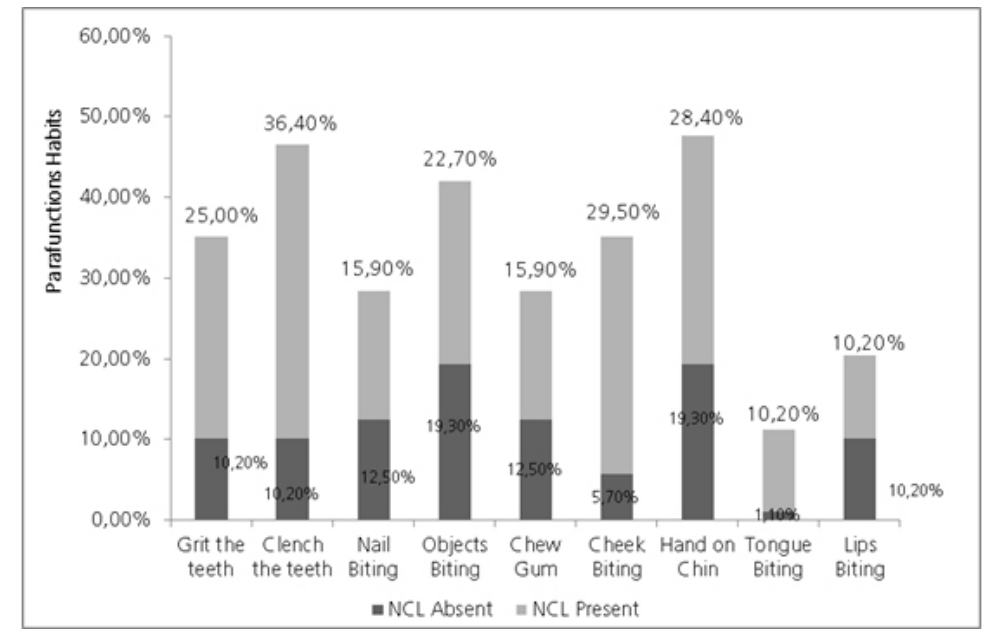

Figure 2. Distribution of the frequency of parafunctional habits in the sample.

$(p=0.040)$ and low correlation between clenching and the presence of $\mathrm{NCL}(\mathrm{V}=0.270)$ (Figure 2$)$.
Unilateral chewing was prevalent in individuals with NCL presence (Figure 3), but associations found 


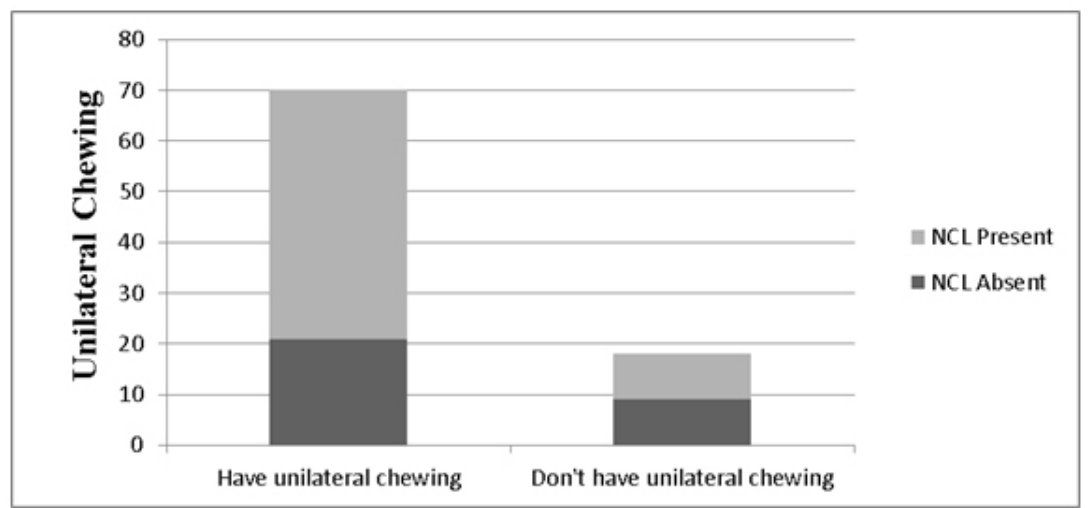

Figure 3. Distribution of the frequency of the Unilateral chewing in the sample.

between these variables were not statistically significant ( $p$ $=0.110$ ).

The lateral disocclusion standard did not correlate with the presence of lesions, although disocclusion by the canine has been prevalent in the sample.The anterior disocclusion presented a moderate correlation $(V=0.336)$ between presenting anterior protrusion but not having $\mathrm{NCL}$. Occlusal interference in $\mathrm{MIH}(\mathrm{V}=0.445)$ and on the

Table 1. Descriptive and inferential statistics of disocclusion pattern, occlusal interferences and the presence of NCLs.

\begin{tabular}{|c|c|c|c|c|c|}
\hline \multirow{2}{*}{ Variables } & \multicolumn{2}{|c|}{ NCL absence } & \multicolumn{2}{|c|}{ NCL present } & \multirow{2}{*}{ Reference values } \\
\hline & $\mathrm{F}$ & $\%$ & $\mathrm{~F}$ & $\%$ & \\
\hline \multicolumn{6}{|l|}{ Right disocclusion } \\
\hline Canina guidance & 17 & 19,3 & 27 & 30,7 & \multirow{3}{*}{$\begin{array}{l}x^{2}=2,780 \\
p=0,249\end{array}$} \\
\hline Group partial & 4 & 4,5 & 17 & 19,3 & \\
\hline Group function & 9 & 10,2 & 14 & 15,9 & \\
\hline \multicolumn{6}{|l|}{ Left discclusion } \\
\hline Canine & 15 & 17,0 & 22 & 25,0 & \multirow{3}{*}{$\begin{array}{l}x^{2}=1,492 \\
p=0,474\end{array}$} \\
\hline Partial in group & 7 & 8,0 & 20 & 22,7 & \\
\hline Function in group & 8 & 9,1 & 16 & 18,2 & \\
\hline \multicolumn{6}{|l|}{ Anterior guidance } \\
\hline Anterior & $23^{*}$ & 26,1 & 24 & 27,3 & \multirow{3}{*}{$\begin{array}{l}x^{2}=9,924 \\
p=0,007 \star\end{array}$} \\
\hline Posterior & 1 & 1,1 & 6 & 6,8 & \\
\hline Combined & 6 & 6,8 & $28 *$ & 31,8 & \\
\hline \multicolumn{6}{|l|}{ Interference in $\mathrm{Ml}$} \\
\hline Absent & $29 *$ & 33,0 & 13 & 14,8 & \multirow{2}{*}{$\begin{array}{l}x^{2}=43,697 \\
p<0,001 *\end{array}$} \\
\hline Present & 1 & 1,1 & $45^{* *}$ & 51,1 & \\
\hline \multicolumn{5}{|l|}{$\begin{array}{l}\text { Interference } \\
\text { Nonwworking side }\end{array}$} & \multirow{3}{*}{$\begin{array}{l}x^{2}=8,429 ; \\
p=0,004\end{array}$} \\
\hline Absent & $25^{*}$ & 28,4 & 30 & 34,1 & \\
\hline Present & 5 & 5,7 & $28^{*}$ & 31,8 & \\
\hline
\end{tabular}

Legend: *Significant Association at $1 \%$ level.

no work side $(\mathrm{V}=0.309)$ showed a moderate correlation with the presence of NCL (Table 1).

Wear facets were observed in 1,751 dental elements in this study, among these 379 also had $\mathrm{NCl}$ lesions. It was observed among the elements without $\mathrm{NCL}$ that the greatest wear frequencies were in lower incisors $(17.20 \%)$, lower premolars $(13.63 \%)$ and the upper incisors (13.34\%). The other groups showed relatively equal distribution, ranging from $10.06 \%$ (molars) to $12.68 \%$ (molars). (Figure 4). In contrast, in the number of teeth with wear and $\mathrm{NCl}$ lesions, those with the highest rates were lower premolars $(21.11 \%)$ and upper premolars (17.68\%).

The remaining dental groups have similar percentages, except the molars, which obtained a frequency of $7.12 \%$ and lower canines with $8.71 \%$. The maxilla $(53.03 \%)$ was the most affected one by the wear 


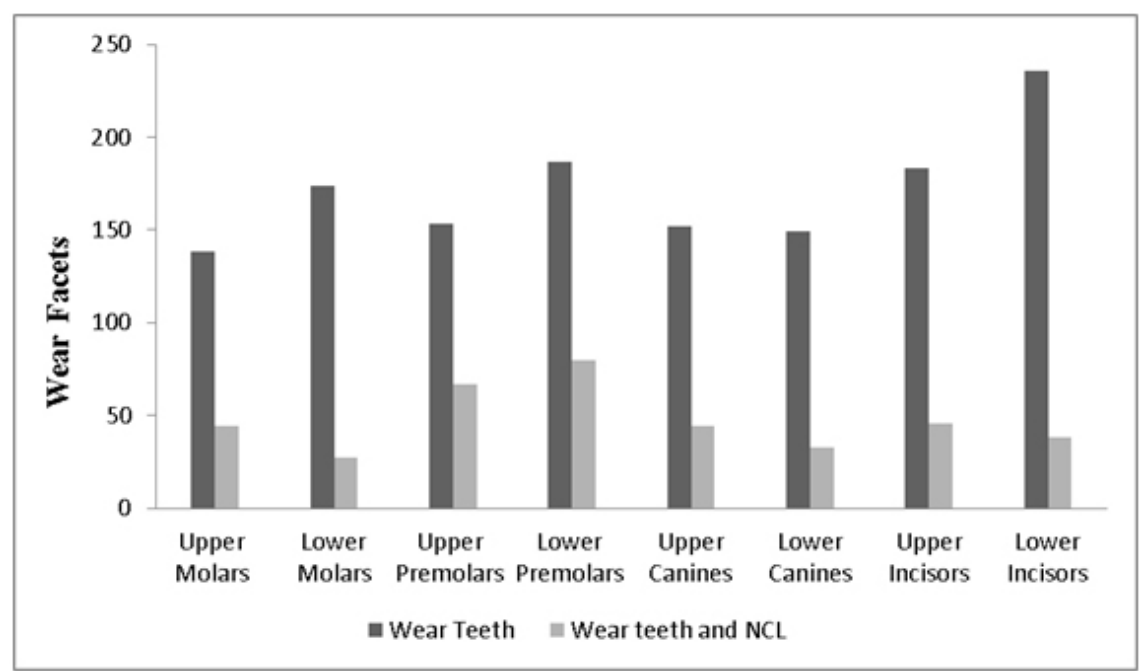

Figure 4. Number of teeth with wear facets in the absence and presence of non-carious cervical lesion.

together with injuries in relation to the mandible (46.97\%) (Figure 4).

Regarding the degree of wear on the dental elements with and without NCL, grade 0 was the prevalent one in groups of molars and premolars. Grade 1, in turn, presented equal distribution in all tooth groups. In grade 2 , it was more expressive the frequency of the lower incisors, although the group of canines, showed similar proportions $(14.23 \%$ to $13.14 \%)$. Finally, the degree 3 of wear was the one which reached the lower frequency compared to the other degrees of wear. Regarding the most prevalent dental group in that degree are the upper incisors (24.69\%)

Table 2. Descriptive statistics of the degree of wear facets in dental groups in the absence and presence of NCL.

\begin{tabular}{|c|c|c|c|c|c|c|c|c|}
\hline \multirow{2}{*}{ Dental groups } & \multicolumn{2}{|c|}{ Degree 0} & \multicolumn{2}{|c|}{ Degree 1} & \multicolumn{2}{|c|}{ Degree 2} & \multicolumn{2}{|c|}{ Degree 3} \\
\hline & $f$ & $\%$ & $\mathrm{~F}$ & $\%$ & $f$ & $\%$ & $\mathrm{~F}$ & $\%$ \\
\hline Upper Molars & 197 & 20,27 & 105 & 10,26 & 15 & 5,47 & 12 & 14,81 \\
\hline Lower Molars & 153 & 15,74 & 140 & 13,69 & 32 & 11,68 & 12 & 14,81 \\
\hline Upper Premolars & 176 & 18,11 & 121 & 11,83 & 22 & 8,03 & 8 & 9,88 \\
\hline Lower premolars & 158 & 16,25 & 140 & 13,69 & 36 & 13,14 & 11 & 13,58 \\
\hline Upper Canine & 25 & 2,57 & 103 & 10,07 & 39 & 14,23 & 7 & 8,64 \\
\hline Lower Canine & 28 & 2,88 & 103 & 10,07 & 36 & 13,14 & 8 & 9,88 \\
\hline Upper Incisives & 136 & 13,99 & 137 & 13,39 & 32 & 11,68 & 20 & 24,69 \\
\hline Lower Incisives & 99 & 10,19 & 174 & 17,01 & 62 & 22,63 & 3 & 3,70 \\
\hline Total & 972 & 100,00 & 1023 & 100,00 & 274 & 100,00 & 81 & 100,00 \\
\hline
\end{tabular}

(Table 2).

It was estimated the relative risk (Odds Ratio - OR) to show the higher number of NCLs and their development or presence for variables of interference in $\mathrm{Ml}$ and no work side and parafunctional habits. The presence of occlusion interference in $\mathrm{MIH}$ increases in 26X the risk of having a higher number of lesions and in 100X the risk of having $\mathrm{NCL}$. Interference in nonworking side suggest $3 X$ or $4 X$ the risk of having a greater number of lesions and the presence

Table 3. Relative risk in developing lesions.

\begin{tabular}{lcccc}
\hline \multirow{2}{*}{ Variables } & \multicolumn{2}{c}{ Higher NCLs number } & \multicolumn{2}{c}{ Presence of NCLs } \\
& OR & IC 95\% & OR & IC 95\% \\
\hline Occlusal interference in MI & $26,640 *$ & $8,289-85,61$ & $100,385^{*}$ & $12,45-809,0$ \\
Occlusal interference in nonworking side & $3,789^{*}$ & $1,521-9,438$ & $4,667 *$ & $1,570-13,87$ \\
Parafunctional habits & 0,320 & $0,059-1,747$ & 0,299 & $0,034-2,605$ \\
\hline
\end{tabular}

Legend: * statistically significant risk. 
of the same respectively. While habits do not apply as risk factors for NCLs (Table 3).

\section{DISCUSSION}

Since the publication of the classic study by Lee \& Eakle $^{9}$, in which stresses caused by excessive occlusal load would be responsible for the development of NCLS, the etiology of these lesions started to be questioned. The clinical evidence on the causal factors of NCLs are important for guiding the dentist concerning the risk variables of the same. And how he may act, guiding his patients or even taking preventive measures to avoid the appearance and progression of these lesions $s^{2-3,6,10,15,17}$.

The research results accept the hypothesis that occlusal factors were associated with the presence of NCLs, and corroborates clinical findings in literature ${ }^{15,17-20}$. However, they noted that lower tension forces in lateral movements do not prevent the progression of the lesion. This result can be questioned, because even if tensions are lower, if they are not axial loads, the occlusal interference continue acting, promoting the progression of lesions. Occlusal interference in $\mathrm{Ml}$ and next to nonworking area are risk factors for the development and a greater number of injuries corroborates the literature ${ }^{18}$. It is interesting to emphasize that the adequate anterior guidance is correlated to the absence of lesions, ie, patients without lesions have fewer interferences ${ }^{17}$.

As well as the prevalence of a normal side disocclusion in a sample that had some kind of altered occlusion, a result that goes agrees with the findings in a similar population ${ }^{19}$.

The occlusal factor is essecial for the development of $\mathrm{NCLS}^{21}$ and explains their presence in the study population as well as in African patients, who had no contact with oral hygiene habits and had lesions. The occlusal loading and the supporting action of acids from drugs and feeding act together for the development of $\mathrm{NCLs}^{21}$.

The wear facets were found in a large number of dental elements, because they are a physiological phenomenon in the population. The combination of factors such as occlusal interferences, diet, abrasive habits, cultural habits and geographical location may influence in their frequency ${ }^{16}$.

However not all dental elements affected by NCL in this sample ${ }^{8}$ showed wear facet. This study, it was not performed statistical inference of this variable for the presence of lesions. The literature suggests that wear facets do not influence the formation of $\mathrm{NCLs}^{22}$. Given this clinical setting, perhaps the wear facet is not a sign of the presence of an injury, however we still needed closer examination of the relationship between wear facets and NCL.

The predilection for the premolars group and maxillary arch of the wear facets on dental elements with injuries; is due to the oclusal stress ${ }^{15,23}$ and the action of abrasion, erosion and parafunctions ${ }^{16}$ respectively.

The prevalence of 0 degree of wear in molars and premolars is due to normal lateral excursions in the sample. The high number of grade 1 wear compared to grade 3 happened because they were samples of young adults who have not been exposed to factors that accentuate tooth loss over the time. And the frequency of degree 3 of wear facet in incisors groups might be related to the repetition of harmful habits, and because the anterior elements are mostly affected by wearing than the posterior ones ${ }^{13}$.

Parafunctional habits are more frequent in patients with $\mathrm{NCL}^{17}$, the occlusal load generated by these habits is higher than the axial loads, causing significant damage to dental tissue ${ }^{12}$. Some studies ${ }^{15,20}$ deny the association of these habits to the presence of lesions. That is, as presented in this research, such habits do not mean risk for the lesions development.

Unilateral chewing was not associated with the presence of lesions, this result is also found by the literature ${ }^{15}$. It is possible that tensions generated during the unilateral masticatory act are not significant for the emergence of non-carious cervical lesions. Moreover, maybe the unilateral chewing is a concern much more muscular than dental.

All study participants have some kind of altered occlusion, being patient occlusion services, but not all had $\mathrm{LCNCs}^{8}$. Since the occlusion factor is related to the presence of injury, how to explain the absence of same in some patients? This is due to the sample is made up of young adults, which has not suffered the action of occlusal stress the right time.

As well, the sample is presented as balanced regarding lateral disocclusion, a positive factor that contributed to this result. The magnitude, duration, direction, frequency and location of occlusal loads 1.4,10-11,23-24, are crucial to initiate and act in the progression of the lesion. And individuals where the injury was absent are considered high risk to present future lesions.

This research enables clinical aesthetic evaluation of the behavior of frontal NCL of occlusal mechanisms. 
Through a controlled and estimated sample made it was possible to compare data with individuals without injury. The limitation of this study is the observation of pathology already installed, so we cannot say that occlusal factors are the initial cause of the injury; can identify them only as risk factors and correlation between variables.

Clinical research must be conducted in an attempt to observe longitudinally the development of these lesions in populations of other dental services in order to identify whether the occlusal factors are initial etiologic agents of development of these non-carious cervical lesions. As well, it is necessary to check for a possible relationship between wear facets and LCNCs.

\section{CONCLUSION}

It was concluded that the parafunctional habits like teeth clenching had a positive association but weak

\section{REFERENCES}

1. Grippo JO, Smiring M, Screiner S. Attrition, abrasion, corrosion and abnfraction revisited $A$ new perspective on tooth surface lesions. J Am Dent Assoc. 2004;135(8):1109-18. doi: 10.14219/ jada.archive.2004.0369

2. Shetty SM, Shetty RG, Mattigatti S, Managoli NA, Rairam SG, Patil AM. No carious cervical lesions: abfraction. J Int Oral Health. 2013;5(5):143-6.

3. Sarode GS, Sarode SC. Abfraction: a review. J Oral Maxillofac Pathol. 2013;17(2):222-7. doi: 10.4103/0973-029X.119788

4. Benazzi S, Nguyen HN, Schulz D, Grosse IR, Gruppioni G, Hublin JJ, et al. The evolutionary paradox of tooth wear: simply destruction or inevitable adaptation? PLoS One. 2013;8(4):e62263. doi: 10.1371/ journal.pone.0062263

5. Antonelli JR, Hottel TL, Garcia-Godoy F. Abfraction lesions--where do they come from? A review of the literature. J Tenn Dent Assoc. 2013;93(1):14-9.

6. Afolabi AO, Shaba OP, Adegbulugbe IC. Clinical investigation of patient related factors in non carious cervical lesions. Nig Q J Hosp Med. 2013;23(2):129-34.

7. Wiegand A, Schlueter N. The role of oral hygiene: does toothbrushing harm? Monogr Oral Sci. 2014;25:215-219. doi: $10.1159 / 000360379$

8. Figueiredo VMG, Santos RL, Batista AUD. Avaliação de hábitos de higiene bucal, hábitos alimentares e $\mathrm{pH}$ salivar em pacientes com ausência e presença de lesões cervicais não cariosas. Rev Odontol UNESP. 2013:42(6):414-9. correlation with the presence of NCLs. Unilateral chewing was not associated with presence of lesions. Canine guidance was common throughout the sample. Occlusal interference in $\mathrm{Ml}$ and nonworking side are risk factors for a higher number of lesions and their development. The premolars and the maxillary arch were the most affected by the wear facets and NCLs.

\section{Collaborators}

VMG FIGUEIREDO, RL SANTOS and AUD BATISTA conducted the research, collected, analyzed, discussed the data and participated in writing the article.

9. Lee WC, Eakle S. Possible role of tensile stress in the etiology of cervical erosive lesions of tecth. J Prosth Dent. 1984;52(2):374-80. doi:10.1016/0022-3913(84)90448-7

10. Romeed SA, Malik R, Dunne SM. Stress analysis of occlusal forces in canine teeth and their role in the development of non-carious cervical lesions: abfraction. Int J Dent. 2012;2012:234845. doi:10.1155/2012/234845

11. Guimarães JC, Guimarães Soella G, Brandão Durand L, Horn F, Narciso Baratieri L, Monteiro S Jr et al. Stress amplifications in dental non-carious cervical lesions. J Biomech. 2014;47(2):4106. doi: 10.1016/j.jbiomech.2013.11.012

12. Ress JS, Jagger DC. Abfraction lesions: Myth or reality? J Esthet Restor Dent. 2003;15(5):263-71.

13. Okeson JP. Tratamento das desordens temporomandibulares e oclusão. São Paulo: Artes Médicas; 2008.

14. Abdullah A, Sherfudhin $H$, Omar R, Johansson A. Prevalence of occlusal tooth wear and its relationship to lateral and protrusive contact schemes in a young adult Indian population. Acta Odontol Scand. 1994;52(4):191-7.

15. Pegoraro LF, Scolaro JM, Conti PC, Telles D, Pegoraro TA. Noncarious cervical lesions in adults Prevalence and occlusal aspects. J Am Dent Assoc. 2005;136(12):1694-700.

16. Permagalian A, Rudy TE, Zaki HS, Greco CM. The association between wear facets, bruxism, and severity of facial pain in pacients with temporomandibular disorders. J Prosthet Dent. 2003;90(2):194-200. 
17. Piotrowski BT, Gillette WB, Hancock EB. Examining the prevalence and characteristics of abfractionlike cervical lesions in a population of U.S. veterans. J Am Dent Assoc. 2001;132(12):1694-701.

18. Bernhardt O, Gesch D, Schawah F, Mack G, Meyer JU, Kocher ET. Epidemiological evaluation of the multifactorial aetiology of abfractions. J Oral Rehabil. 2006;33(1):17-25. doi: 10.1111/j.1365-2842.2006.01532.x

19. Miller N, Penaud J, Ambrosini P, Bisson-Boutelliez C, Briançon S. Analysis of etiologic factors and periodontal conditions involved with 309 abfractions. J Clin Periodontol. 2003;30(9):828-32. doi: 10.1034/j.1600-051X.2003.00378.x

20. Oliveira ACS, Damascena NP, Souza CS. Análise clínica de pacientes portadores de lesões cervicais não cariosas e sua relação com hábitos. Rev Sul-Bras.Odontol. 2010;7:182-92.

21. Faye B, Kane AW, Sarr M, Lo C, Ritter AV, Grippo JO. Noncarious cervical lesions among a non-toothbrushing population with Hansen's disease (leprosy): initial findings. Quintessence Int. 2006; 37:613-9.
22. Sadaf $D$, Ahmad Z. Role of brushing and occlusal forces in noncarious cervical lesions (NCCL). Int J Biomed Sci. 2014;10(4):2658.

23. Benazzi S, Grosse IR, Gruppioni G, Weber GW, Kullmer O. Comparison of occlusal loading conditions in a lower second premolar using three-dimensional finite element analysis. Clin Oral Investig. 2014;18(2):369-75.
Received on: 21/1/2015 Final version resubmitted on: 7/8/2015 Approved on: 26/9/2015 